\title{
REPERCUSSIONS OF THE COVID-19 PANDEMIC ON THE MENTAL HEALTH OF PREGNANT AND PUERPERAL WOMEN: A SYSTEMATIC REVIEW
}

Leticia Genova Vieira ${ }^{1}$, Emerson Lucas Junior Silva Camargo², Guilherme Schneider ${ }^{1}$, Gabrielly Pereira Rocatti da Silva², Micaella Thomazini², Matheus Arantes Possani², Matheus Rozário Matioli² ${ }^{2}$ Aline Raquel de Sousa Ibiapina ${ }^{3}$

${ }^{1}$ University of São Paulo, Ribeirão Preto, Brazil.

${ }^{2}$ University of Ribeirão Preto, Ribeirão Preto, Brazil

${ }^{3}$ Federal University of Piauí, Teresina, Brazil

Correspondence Address

Emerson Lucas Junior Silva Camargo

University of Ribeirão Preto, Ribeirão Preto, Brazil

Av. Costábile Romano, 2201 - Nova Ribeirânia, Ribeirão Preto - SP, 14096-900

$+55163603-7001$

Email:lucmrg0@gmail.com

\section{ABSTRACT}

Background: The Coronavirus Disease 2019 (COVID-19) pandemic has caused negative impacts on the physical and mental health of the population worldwide. Pregnant and puerperal women comprise the population most vulnerable to impacts on mental health.

Objective: To synthesize the scientific evidence on the repercussions of the COVID-19 pandemic on the mental health of pregnant and puerperal women.

Methods: systematic review focused on answering the question "what is the impact of the COVID-19 pandemic on the mental health of pregnan and puerperal women?". In order to perform the search of the studies, we used combinations among the keywords: pregnan*, puerper*, prenatal, perinatal, “mental health", COVID-19, SARS-CoV-2. In total, we identified 150 studies from the databases and 14 studies were selected from preprints. We identified another four studies through manual search, totaling 18 studies to compose the final sample of this review.

Results: Anxiety and depression were the main outcomes found, being shown in 15 and 11 studies, respectively. Other outcomes found in more than one study were: concerns related to several factors, loneliness, stress and fear. 
Conclusion: From this review, we can infer that the COVID-19 pandemic has impacted the mental health of pregnant and puerperal women, with depression and anxiety being the most frequent changes. The social detachment, the media pressure, the fear of contracting the infection, the economic scenario and the rupture of family rituals are shown as intensifying factors of psychological distress, thus causing changes in the mental health of these women.

Keywords: Pregnant, Puerperal, Mental Health, Pandemic, COVID-19, SARS-CoV-2.

\section{INTRODUCTION}

The onset of emerging infectious diseases has been considered a major public health problem worldwide. Atypical cases of pneumonia, severe respiratory disease and sudden impairment of other organs appeared in the city of Wuhan, Hubei province, China, in December 2019, caused by Severe Acute Respiratory Syndrome Coronavirus 2, SARSCoV-2, etiologic agent of Coronavirus Disease 2019, COVID-19 [1].

With the exponential growth of COVID-19 on a transcontinental basis, the World Health Organization (WHO) declared, on March $11^{\text {th }}, 2020$, that COVID-19 qualified as a pandemic. Although the disease has low lethality, which ranges from $0.2 \%$ to $14.8 \%$, its worsening is associated with an increase in the age group and the clinical impairment of pre-existing diseases. Its transmissibility is high, reaching about $80 \%$ of mild cases of acute respiratory syndrome, where between $5 \%$ and $10 \%$ of cases progress to severe symptoms of respiratory failure [2]. Respiratory secretions are the main source of the spread of COVID19 [3]. Moreover, COVID-19 is capable of causing neurological, hepatic, respiratory and enteric changes [4].

Since the WHO declaration, health agencies have adopted measures to protect and prevent the spread of the illness, such as social detachment, the use of personal protective equipment (PPE) and non-pharmaceutical strategies, such as hand washing [5]. The adoption of prevention and control measures are part of the strategic actions aimed at the population or groups with a higher risk of infection, and the adoption of measures to halt the spread of the virus has caused an impact on health results, mainly on the mental health of the population, especially in pregnant and puerperal women [6]. 
Women in gestational and puerperal periods are groups considered to be at risk, given the greater chances for serious complications and lethality [7]. Accordingly, the primary and hospital health care services adopted the reorganization of care flows and specific strategies for the clinical-care management of these women, aiming at reducing the number of cases of COVID-19. In view of the above, the assistance during childbirth, birth and follow-up of the parturient woman must comply with all technical recommendations in symptomatic, asymptomatic or positive cases for COVID-19, aiming at protecting the health of women and newborns [8].

The rapid spread, the lack of discovery of effective treatment, the unpredictability of the duration of the pandemic, the disclosure of false information, known as fake news, and the shortage of understanding of the population in complying with the recommendations of health authorities are characterized as factors risk factors for the impact on mental health [9].

The increase in fake news published on social media has also increased stress, fear and anxiety about the disease, since the way some information is exposed has generated negative consequences on the mental health of the population, in some moments of this pandemic, especially in women during gestational and puerperal periods [10].

In view of the pandemic scenario, the disclosure of scientific knowledge worldwide has been happening in a skilful way about information concerning COVID-19. Nevertheless, studies associated with the impact of the pandemic on the mental health of pregnant and puerperal women are scarce, as the event is recent, but highlights negative factors. Thus, this study had the objective of synthesizing the scientific evidence on the repercussions of the COVID-19 pandemic on the mental health of pregnant and puerperal women.

\section{METHOD}

This is a systematic literature review [11] without registration of a protocol, with a framework based on the recommendations of The Joanna Briggs Institute (JBI), which consists of the systematic and orderly grouping of scientific evidence on a given topic, in order to allow the association between factors and development of a condition (health outcome), based on a strictly structured process, thus ensuring that the results achieved are reliable and significant. 
We performed six steps to develop this review, namely: 1) definition of the objective and construction of the guiding question; 2) definition of the search strategy; 3) definition of the inclusion and exclusion criteria and the data to be extracted from the studies; 4) selection of the studies; 5) characterization of the studies and synthesis of the pertinent data; 6) interpretation and presentation of the review.

The guiding question of this review "What is the impact of the COVID-19 pandemic on the mental health of pregnant and puerperal women?" was constructed with the aid of the PICOS strategy, as displayed in Table 1.

Table 1. Application of the PICOS strategy for the construction of the research question. Ribeirão Preto, SP, Brazil, 2020.

\begin{tabular}{|l|l|l|}
\hline Acronym & Definition & Description \\
\hline $\mathrm{P}$ & Population or problem & Pregnant and/or puerperal women \\
\hline $\mathrm{I}$ & Intervention or interest & COVID-19 pandemic \\
\hline $\mathrm{C}$ & Comparison & Not applicable \\
\hline $\mathrm{O}$ & Outcome & Impact on Mental Health \\
\hline $\mathrm{S}$ & Study type & $\begin{array}{l}\text { Original studies with a qualitative } \\
\text { approach }\end{array}$ \\
\hline
\end{tabular}

Source: authors.

The bibliographical survey was held during the month of July 2020, taking place in the following electronic databases: MEDLINE via PubMed portal of the US National Library of Medicine, Web of Science (WoS), Excerpta Medica Database (EMBASE), SCOPUS and APA PsycNet, in addition to the MedRxiv and PsyArXiv preprint databases. In order to complement the present study with the other evidence regarding the topic, we performed a manual search.

For the MEDLINE, WoS, EMBASE, SCOPUS, APA PsycNet databases and for the PsyArXiv preprint database, we used the following combination of keywords and Boolean operators: (pregnan* OR puerper* OR prenatal OR perinatal) AND “mental health"AND (COVID-19 OR SARS-CoV-2). For the MedRxiv preprint database, we used the following search strategy: (pregnancy OR pregnant OR puerperium OR puerperal OR prenatal OR perinatal) AND “mental health” AND (COVID-19 OR SARS-CoV-2). 
We should underline that no filters were added as to the language and period of publication of scientific studies, with a view to encompassing the largest possible amount of evidence related to the problem in question.

Accordingly, we identified a total of 150 scientific works in the databases and preprint. Table 2 shows the number of studies retrieved from each queried database.

Table 2. Number of studies identified in each database regarding the impact of the COVID19 pandemic on the mental health of pregnant and puerperal women. Ribeirão Preto, SP, Brazil, 2020.

\begin{tabular}{|l|l|}
\hline Electronic databases and preprint & Number of identified studies \\
\hline MEDLINE & 28 \\
\hline WOS & 11 \\
\hline EMBASE & 52 \\
\hline SCOPUS & 34 \\
\hline APA PsycNet & 7 \\
\hline PsyArXiv & 2 \\
\hline medRxiv & 16 \\
\hline TOTAL & $\mathbf{1 5 0}$ \\
\hline
\end{tabular}

Source: authors.

Among the 150 identified studies, 69 were removed due to duplication in at least two databases. Thus, the titles and abstracts of the 81 screened studies were analyzed, by two reviewers, independently and blindly. For any disagreements between the researchers during the analytic process, we called a third researcher for resolution. After the considerations of the third reviewer, we performed a manual search based on the references of the secondary articles obtained in the search in the databases.

We established inclusion criteria for all primary studies that evaluated the mental health of pregnant and puerperal women during the COVID-19 pandemic. In turn, the adopted exclusion criteria were: secondary studies, expert opinion articles, experience reports and other scientific works that did not meet the scope of this review.

Thus, we selected 18 studies to compose the final sample of this systematic literature review, aiming at synthesizing the evidence on the impact of the COVID-19 pandemic on the mental health of pregnant and puerperal women. The studies were identified according to adaptations of the recommendations of the Preferred Reporting Items for Systematic Reviews and Meta-Analyses (PRISMA), as displayed in Flowchart 1 [12]. 
Flowchart 1. Schematized chart of the process of identification and selection of the studies to be included in this review, regarding the impact of the COVID-19 pandemic on the mental health of pregnant and puerperal women, according to the adaptation of the PRISMA model. Ribeirão Preto, SP, Brazil, 2020.

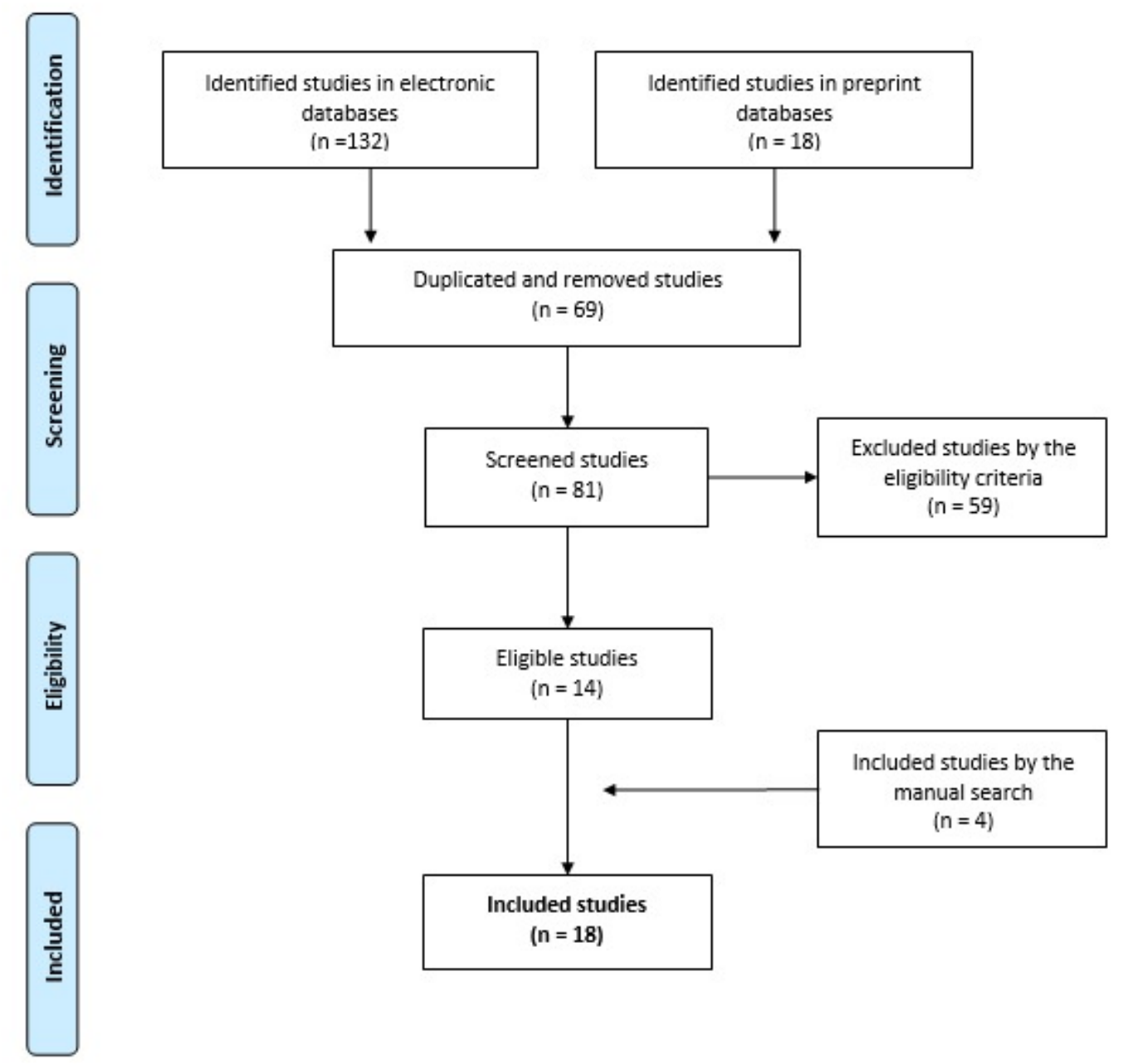

Source: authors.

In this study, we analyzed the quality of the evidence levels of the included studies using the classification of the Grading of Recommendations, Assessment, Development and Evaluation Working Group (GRADE). The quality of the evidence obtained through the GRADE allows us to analyze the aggregated results, considering the design and the results of the included studies [13]. 
The data from the selected studies were extracted and grouped in a table (Table 3) containing specific information related to the research question, namely: author (s); year of publication; country where the research was held; component population and its main characteristics; study design; instruments and/or means used to evaluate mental health status; main outcomes related to the impact of the COVID-19 pandemic on the mental health of pregnant and puerperal women; level of evidence; and main limitations of the studies.

As this study used articles of public and free access, indexed in the electronic databases, the submission process in the Research Ethics Committee (CEP), according to the Resolution of the National Health Council (CNS) no 466/2012, as well as the current ethical ethical standards, was not necessary.

\section{RESULTS}

We analyzed 18 studies that identified the impact on the mental health of pregnant and puerperal women during the period of the COVID-19 pandemic. In order to perform the qualitative synthesis of the selected articles, we drew up a table that summarizes the main characteristics of the included studies [14-31], containing information regarding the reference, the location and the population, the design, the outcome, the level of evidence and 
Table 3. Characterization of the studies included in the final sample of this systematic review regarding the reference; the location and the population; the study design; the evaluation instrument; outcomes; the level of evidence and; the main limitations. Ribeirão Preto, SP, Brazil, 2020.

\begin{tabular}{|c|c|c|c|c|c|c|}
\hline Code & Location / Population & Study design & $\begin{array}{l}\text { Evaluation } \\
\text { instrument }\end{array}$ & $\begin{array}{l}\text { Outcomes (impacts on mental } \\
\text { health) }\end{array}$ & $\begin{array}{l}\text { Level of } \\
\text { evidence }\end{array}$ & Limitations \\
\hline$[14]$ & $\begin{array}{l}\text { London, United Kingdom. } \\
11 \text { mothers with confirmed } \\
\text { diagnosis of COVID-19, age } \\
\text { range between } 18 \text { and } 39 \text { years } \\
\text { and deliveries between the } 27^{\text {th }} \\
\text { and } 39^{\text {th }} \text { weeks of pregnancy. }\end{array}$ & $\begin{array}{l}\text { Descriptive } \\
\text { cross- } \\
\text { sectional } \\
\text { study. }\end{array}$ & $\begin{array}{l}\text { GAD-7 and } \\
\text { PHQ-9. }\end{array}$ & $\begin{array}{l}\text { Low levels of anxiety and } \\
\text { depression. }\end{array}$ & Low. & $\begin{array}{l}\text { - Small sample size. } \\
-\quad \text { Restricted to a single } \\
\text { institution. } \\
\text { - Without long-term follow-up. }\end{array}$ \\
\hline$[15]$ & $\begin{array}{l}\text { Qazvin, Iran. } \\
290 \text { pregnant women, with an } \\
\text { average age of } 29 \text { years and an } \\
\text { average gestational age of } 15 \\
\text { weeks. }\end{array}$ & $\begin{array}{l}\text { Descriptive } \\
\text { cross- } \\
\text { sectional } \\
\text { study. }\end{array}$ & $\begin{array}{lr}\text { APIM, } & \text { FCV- } \\
\text { 19S, } & \text { HADS, } \\
\text { SF-12, } & \text { PHQ-9 } \\
\text { and PCV-19BS. }\end{array}$ & $\begin{array}{l}\text { The fear caused by COVID-19 } \\
\text { in pregnant and puerperal } \\
\text { women was related to the } \\
\text { occurrence of depression, } \\
\text { suicidal thoughts and worse } \\
\text { mental health in this population. }\end{array}$ & $\begin{array}{l}\text { Very } \\
\text { low. }\end{array}$ & $\begin{array}{l}\text { - Study design. } \\
\text { - Data based on self-report } \\
\text { measures. } \\
\text { - Potential for social desirability } \\
\text { bias. } \\
\text { - Memory bias. } \\
\text { - Without long-term follow-up. }\end{array}$ \\
\hline$[16]$ & $\begin{array}{l}\text { Bangalore, India. } \\
\text { A 24-year-old woman, two } \\
\text { months postpartum, without } \\
\text { family history or previous } \\
\text { psychiatric disorder, and negative } \\
\text { RT-PCR test for SARS-CoV-2. }\end{array}$ & Case report. & $\begin{array}{l}\text { Clinical } \\
\text { evaluation. }\end{array}$ & $\begin{array}{l}\text { Psychotic signs and symptoms: } \\
\text { anxiety, agitation, irrelevant } \\
\text { speech, crying spells, delusions } \\
\text { of persecution, overvalued idea } \\
\text { that she had contracted COVID- } \\
19 \text { and was transmitting to his } \\
\text { son, fear of contracting COVID- } \\
19 \text {, catatonic symptoms of } \\
\text { mutism and facing. } \\
\text { Medical diagnosis: acute } \\
\text { polymorphic psychosis. }\end{array}$ & Low. & $\begin{array}{l}\text { - Small sample size. } \\
-\quad \text { Restricted to a single } \\
\text { institution. }\end{array}$ \\
\hline
\end{tabular}




\begin{tabular}{|c|c|c|c|c|c|c|}
\hline & & & & $\begin{array}{l}\text { Consequences during the } \\
\text { psychotic break: refusal to } \\
\text { breastfeed. }\end{array}$ & & \\
\hline [17] & $\begin{array}{l}\text { Hangzhou, China. } \\
\text { A } 30 \text {-year-old woman, } 35 \text { weeks } \\
\text { and two days pregnant, RT-PCR } \\
\text { positive test for SARS-CoV-2 and } \\
\text { gave birth two days after her } \\
\text { diagnosis. }\end{array}$ & Case report. & $\begin{array}{l}\text { Clinical } \\
\text { interview, } \\
\text { HAMD-17, } \\
\text { MADRS and } \\
\text { HAMA. }\end{array}$ & $\begin{array}{l}\text { Signs and symptoms in the } \\
\text { psychiatric clinic interview: bad } \\
\text { mood, irritability, excessive } \\
\text { health concerns, as well as with } \\
\text { the newborn child, husband and } \\
\text { close relatives, intense feeling of } \\
\text { guilt, depression, sad facial } \\
\text { expression, anxious emotion, } \\
\text { occasional restlessness. } \\
\text { Signs and symptoms measured } \\
\text { during dialectical behavior } \\
\text { therapy: st session: high scores } \\
-1^{\text {st }} \text { depression and } \\
\text { anxiety; } \\
-2^{\text {nd }} \text { session: decreased } \\
\text { scores, but symptoms of } \\
\text { depression and anxiety } \\
\text { present; } \\
-3^{\text {rd }} \text { session: low scores } \\
\text { with relief of symptoms } \\
\text { of depression and } \\
\text { anxiety. }\end{array}$ & $\begin{array}{l}\text { Very } \\
\text { low. }\end{array}$ & $\begin{array}{l}\text { - Small sample size. } \\
\text { - Restricted to a single } \\
\text { institution. } \\
\text { - Only one intervention. } \\
\text { - Only three therapy sessions. } \\
\text { - Without long-term follow-up. }\end{array}$ \\
\hline [18] & $\begin{array}{l}\text { Canada. } \\
1987 \text { pregnant women, with an }\end{array}$ & $\begin{array}{l}\text { Descriptive } \\
\text { cross- }\end{array}$ & $\begin{array}{l}\text { EPDS, } \\
\text { PROMIS, }\end{array}$ & $\begin{array}{l}\text { Women reported feelings of } \\
\text { loneliness, concerns with their }\end{array}$ & Low. & $\begin{array}{l}\text { - Absence of interventions. } \\
\text { - Without long-term follow-up }\end{array}$ \\
\hline
\end{tabular}




\begin{tabular}{|c|c|c|c|c|c|c|}
\hline & $\begin{array}{l}\text { average age of } 32 \text { years and a } \\
\text { gestational age of less than } 35 \\
\text { weeks. }\end{array}$ & $\begin{array}{l}\text { sectional } \\
\text { study. }\end{array}$ & $\begin{array}{l}\text { PRAQ, } \\
\text { SSEQ and } \\
\text { ISEL }\end{array}$ & $\begin{array}{l}\text { lives and the babies. They } \\
\text { presented high depression, } \\
\text { general anxiety and pregnancy- } \\
\text { related anxiety scores. }\end{array}$ & & and support. \\
\hline [19] & $\begin{array}{l}\text { China. } \\
4124 \text { pregnant women, in the } 3^{\text {rd }} \\
\text { trimester of pregnancy, } 2839 \text { of } \\
\text { whom were evaluated between } \\
\text { January } 1^{\text {st }} \text { and } 20^{\text {th }}, 2020 \text {, and } \\
1285 \text { were evaluated between } \\
\text { January } 21^{\text {st }} \text { and February } 9^{\text {th }} \text {, } \\
2020 .\end{array}$ & $\begin{array}{l}\text { Multicenter } \\
\text { cross- } \\
\text { sectional } \\
\text { study. }\end{array}$ & EPDS. & $\begin{array}{l}\text { On January } 20^{\text {th }}, 2020 \text {, the WHO } \\
\text { declared that SARS-CoV-2 has } \\
\text { human-to-human transmission. } \\
\text { Pregnant women evaluated after } \\
\text { the SARS-CoV-2 pandemic } \\
\text { declaration presented higher } \\
\text { anxiety scores, as well as } \\
\text { depressive symptoms, than those } \\
\text { evaluated before the declaration, } \\
\text { in addition to self-mutilation } \\
\text { thoughts. }\end{array}$ & Low. & $\begin{array}{l}\text { - Data based on self-report } \\
\text { measures. } \\
\text { - Scale used had the purpose of } \\
\text { screening, and not making a } \\
\text { diagnosis. } \\
\text { - Absence of intervention. } \\
\text { - Without long-term follow-up. }\end{array}$ \\
\hline [20] & $\begin{array}{l}\text { United Kingdom. } \\
1365 \text { women, aged over } 18 \text { and } \\
\text { babies up to } 12 \text { months. }\end{array}$ & $\begin{array}{l}\text { Descriptive } \\
\text { cross- } \\
\text { sectional } \\
\text { study. }\end{array}$ & $\begin{array}{lr}\text { The } & \text { Covid-19 } \\
\text { New } & \text { Mum } \\
\text { Survey. } & \end{array}$ & $\begin{array}{l}146 \text { women reported that the } \\
\text { lockdown in the United } \\
\text { Kingdom, due to the COVID-19 } \\
\text { pandemic, had affected their } \\
\text { mental health, causing anxiety, } \\
\text { depression, isolation and } \\
\text { loneliness. }\end{array}$ & Low. & $\begin{array}{l}\text { - Low diversity of participants. } \\
\text { - Pre-existing inequality and } \\
\text { social and health differences. } \\
\text { - There is a need to encourage } \\
\text { the use of health services. }\end{array}$ \\
\hline [21] & $\begin{array}{l}\text { Quebec, Canada. } \\
1258 \text { pregnant women, aged } \\
\text { between } 18 \text { and } 46 \text { years and with } \\
\text { an average gestational age of } 24 \\
\text { weeks, with some history of } \\
\text { psychiatric disorder. } \\
\text { Pre-COVID group (April } 2018 \text { to } \\
\left.\text { March } 1^{\text {st }}, 2020\right) n=496 .\end{array}$ & $\begin{array}{l}\text { Prospective } \\
\text { cohort study. }\end{array}$ & $\begin{array}{l}\text { K10, PCL-5, } \\
\text { DES } \square \text { II and } \\
\text { PANAS. }\end{array}$ & $\begin{array}{l}\text { The pregnant women presented } \\
\text { an increase in depressive and } \\
\text { anxiety symptoms, which can be } \\
\text { defined as high psychological } \\
\text { distress, high negative } \\
\text { affectivity and low positive } \\
\text { affectivity, in addition to } \\
\text { symptoms of dissociation and } \\
\text { post-traumatic stress disorder. }\end{array}$ & Low. & $\begin{array}{l}\text { - Difference in recruitment } \\
\text { methods between the two } \\
\text { cohorts. } \\
\text { - Impossibility of making } \\
\begin{array}{l}\text { comparisons } \\
\text { respondents with } \\
\text { respondents. }\end{array}\end{array}$ \\
\hline
\end{tabular}




\begin{tabular}{|c|c|c|c|c|c|c|}
\hline & $\begin{array}{l}\text { COVID Group (March } 2^{\text {nd }} \text { to } \\
\left.\text { April } 13^{\text {th }}, 2020\right) \mathrm{n}=1259 . \\
\text { Public Health Emergency } \\
\text { declared on March } 13^{\text {th }}, 2020 .\end{array}$ & & & & & \\
\hline [22] & $\begin{array}{l}\text { Belgium. } \\
5866 \text { women, } 2421 \text { pregnant and } \\
3445 \text { postpartum. }\end{array}$ & $\begin{array}{l}\text { Descriptive } \\
\text { cross- } \\
\text { sectional } \\
\text { study. }\end{array}$ & $\begin{array}{l}\text { EDS and GAD- } \\
7 .\end{array}$ & $\begin{array}{l}\text { Increased likelihood of } \\
\text { depressive symptoms and } \\
\text { anxiety among pregnant and } \\
\text { puerperal women during the } \\
\text { lockdown decreed in Belgium, } \\
\text { due to the COVID-19 pandemic. }\end{array}$ & Low. & $\begin{array}{l}\text {-Restricted to a single institution. } \\
\text { - Data based on self-report } \\
\text { measures. } \\
\text { - Without long-term follow-up. } \\
\text { - Little information regarding } \\
\text { mental health care for pregnant } \\
\text { and puerperal women. }\end{array}$ \\
\hline [23] & $\begin{array}{l}\text { Japan. } \\
132 \text { puerperal women before the } \\
\text { pandemic (March } 9^{\text {th }} \text { to April } 11^{\text {th }} \text {, } \\
2019 \text { ) and } 148 \text { puerperal women } \\
\text { during the pandemic (March } 11^{\text {th }} \\
\text { to April } 13^{\text {th }}, 2020 \text { ). }\end{array}$ & $\begin{array}{l}\text { Analytical } \\
\text { cross- } \\
\text { sectional } \\
\text { study. }\end{array}$ & $\begin{array}{l}\text { EPDS } \quad \text { and } \\
\text { MIBS-J. }\end{array}$ & $\begin{array}{l}\text { Depressive symptoms signalized } \\
\text { a worse mother-baby connection } \\
\text { during the pandemic period. }\end{array}$ & $\begin{array}{l}\text { Very } \\
\text { low. }\end{array}$ & $\begin{array}{l}\text {-Small sample size. } \\
\text { - Only puerperal women one } \\
\text { month after the baby is born. } \\
\text { - Without long-term follow-up. } \\
\text { - Absence of support strategies } \\
\text { for mental health. }\end{array}$ \\
\hline [24] & $\begin{array}{l}\text { Colorado, United States. } \\
27 \text { women, aged between } 24 \text { and } \\
45 \text { years, } 14 \text { pregnant and } 13 \\
\text { puerperal women. }\end{array}$ & $\begin{array}{l}\text { Mixed, } \\
\text { exploratory } \\
\text { method. }\end{array}$ & $\begin{array}{l}\text { Semi-structured } \\
\text { interview, } \\
\text { PHQ-2, GAD-7, } \\
\text { BRS, } \\
\text { WEMWBS and } \\
\text { Solitude Scale. }\end{array}$ & $\begin{array}{l}\text { Since the beginning of the } \\
\text { COVID-19 pandemic, pregnant } \\
\text { and puerperal women have } \\
\text { became more likely to } \\
\text { experience symptoms of stress, } \\
\text { depression, anxiety, poor well- } \\
\text { being, resilience and loneliness. }\end{array}$ & $\begin{array}{l}\text { Very } \\
\text { low. }\end{array}$ & $\begin{array}{l}\text { - Small sample size. } \\
\text { - Minimum diversity. } \\
\text {-Lack of presentation of } \\
\text { complications during pregnancy } \\
\text { and childbirth. } \\
\text { - Recruitment strategy. } \\
\text { - Without long-term follow-up. } \\
\text { - Absence of support strategies. }\end{array}$ \\
\hline [25] & $\begin{array}{l}\text { Qingdao, China. } \\
308 \text { pregnant women in the third } \\
\text { trimester. }\end{array}$ & $\begin{array}{l}\text { Descriptive } \\
\text { cross- } \\
\text { sectional } \\
\text { study. }\end{array}$ & $\begin{array}{l}\text { SAS, SSRS and } \\
\text { Self-made } \\
\text { questionnaire. }\end{array}$ & $\begin{array}{l}\text { In the third trimester, pregnant } \\
\text { women presented themselves as } \\
\text { a population at high risk of } \\
\text { developing anxiety. }\end{array}$ & $\begin{array}{l}\text { Very } \\
\text { low. }\end{array}$ & $\begin{array}{l}\text {-Absence of a comparative study } \\
\text { between pregnant women and the } \\
\text { general population during the } \\
\text { COVID-19 outbreak. } \\
\text { - Only pregnant women in the }\end{array}$ \\
\hline
\end{tabular}




\begin{tabular}{|c|c|c|c|c|c|c|}
\hline & & & & & & $\begin{array}{l}\text { third trimester of pregnancy. } \\
\text { - Restricted to a single } \\
\text { institution. } \\
\text { - Data based on self-report } \\
\text { measures. } \\
\text { - Without long-term follow-up. } \\
\text { - Absence of support strategies. }\end{array}$ \\
\hline [26] & $\begin{array}{l}\text { Verona, Italy. } \\
\text { A } 36 \text {-year-old woman, } 35 \text { weeks } \\
\text { pregnant, hospitalized for severe } \\
\text { COVID- } 19 \text { and with a family } \\
\text { history of bipolar disorder. }\end{array}$ & Case report. & Not applicable. & $\begin{array}{l}\text { The pregnant woman presented } \\
\text { a manic episode with serious } \\
\text { psychotic characteristics and } \\
\text { grandiose delusions. }\end{array}$ & $\begin{array}{l}\text { Very } \\
\text { low. }\end{array}$ & $\begin{array}{l}\text { - Small sample size. } \\
\text { - Restricted to a single } \\
\text { institution. } \\
\text { - Absence of complete personal } \\
\text { and family history. } \\
\text { - Lack of similar studies on the } \\
\text { occurrence of psychosis in } \\
\text { pregnant and puerperal women. } \\
\text { - Without long-term follow-up. }\end{array}$ \\
\hline [27] & $\begin{array}{l}\text { Australia. } \\
147 \text { mothers who sought The } \\
\text { Australian Breastfeeding } \\
\text { Association (ABA) because of } \\
\text { concerns about COVID-19, from } \\
\text { March } 16^{\text {th }} \text { to May } 18^{\text {th }}, 2020 \text {. }\end{array}$ & $\begin{array}{l}\text { Descriptive } \\
\text { cross- } \\
\text { sectional } \\
\text { study. }\end{array}$ & Not applicable. & $\begin{array}{l}\text { ABA volunteers identified } \\
\text { emotional well-being concerns } \\
\text { related to COVID-19 and } \\
\text { reported that } 31 \text { mothers were in } \\
\text { difficult isolation by COVID-19, } \\
53 \text { mothers were anxious or } \\
\text { stressed by COVID-19 and } 63 \\
\text { mothers needed tranquility in the } \\
\text { face of the COVID-19 situation. }\end{array}$ & $\begin{array}{l}\text { Very } \\
\text { low. }\end{array}$ & $\begin{array}{l}\text {-Failure to use an instrument to } \\
\text { evaluate levels of stress and } \\
\text { anxiety. } \\
\text { - Lack of information about the } \\
\text { women described in the study. } \\
\text { - Data based on the impressions } \\
\text { of the volunteers themselves. } \\
\text { - Absence of intervention. } \\
\text { - Without long-term follow-up. }\end{array}$ \\
\hline [28] & $\begin{array}{l}\text { Ireland. } \\
71 \text { pregnant women in the second } \\
\text { and third trimesters of pregnancy, } \\
\text { evaluated between March } 16^{\text {th }} \text { and } \\
27^{\text {th }}, 2020 \text {. }\end{array}$ & $\begin{array}{l}\text { Descriptive } \\
\text { cross- } \\
\text { sectional } \\
\text { study. }\end{array}$ & $\begin{array}{l}\text { Did not mention } \\
\text { the instrument } \\
\text { used. }\end{array}$ & $\begin{array}{l}\text { Pregnant women showed greater } \\
\text { concern with their own health } \\
\text { after the onset of the pandemic } \\
\text { than before the pandemic. } \\
50.7 \% \text { ( } 36 \text { out of } 71 \text { ) of the } \\
\text { pregnant women reported } \\
\text { frequent concerns about their }\end{array}$ & Low. & $\begin{array}{l}\text {-Absence of information about } \\
\text { the women described in the } \\
\text { study. } \\
\text { - Absence of information about } \\
\text { the institution. } \\
\text { - Absence of information about } \\
\text { the method of evaluation of the }\end{array}$ \\
\hline
\end{tabular}




\begin{tabular}{|c|c|c|c|c|c|c|}
\hline & & & & $\begin{array}{l}\text { own health, } 66.7 \% \text { ( } 28 \text { out of } \\
42) \text { concerns about their children } \\
\text { and } 63.4 \% \text { ( } 45 \text { out of } 71) \text { about } \\
\text { the unborn baby. Moreover, } \\
83.3 \% \text { (55 out of } 66) \text { reported } \\
\text { increased anxiety about the } \\
\text { health of their older relatives. }\end{array}$ & & $\begin{array}{l}\text { pregnant women. } \\
\text { - Data based on self-report } \\
\text { measures. } \\
\text { - Without long-term follow-up. } \\
\text { - Absence of support strategies. }\end{array}$ \\
\hline [29] & $\begin{array}{l}\text { Israel. } \\
336 \text { Israeli women, } 225 \text { of them } \\
\text { Jewish and } 111 \text { Arabs, aged } \\
\text { between } 20 \text { and } 47 \text { years and } \\
\text { gestational age between four and } \\
41 \text { weeks, evaluated between } \\
\text { March } 18^{\text {th }} \text { and } 28^{\text {th }}, 2020 \text {, who } \\
\text { were unaware of SARS-CoV-2 } \\
\text { infection. }\end{array}$ & $\begin{array}{l}\text { Descriptive } \\
\text { cross- } \\
\text { sectional } \\
\text { study. }\end{array}$ & $\begin{array}{l}\text { Self-developed } \\
\text { questionnaire } \\
\text { and MHI-5. }\end{array}$ & $\begin{array}{l}\text { The evaluated pregnant women } \\
\text { showed high levels of anxiety } \\
\text { due to COVID-19, being related } \\
\text { to the use of public transport } \\
(87.5 \%) \text {, the potential for } \\
\text { infection of other family } \\
\text { members ( } 71.7 \%) \text {, the } \\
\text { permanence in public places } \\
\text { ( } 70 \%) \text {, concerns with the fetus } \\
\text { (70\%), the accomplishment of } \\
\text { pregnancy tests (68.7\%), the fear } \\
\text { of becoming infected (59.2\%), } \\
\text { as well as concerns about } \\
\text { childbirth (55.4\%). Only } 38.1 \% \\
\text { of the pregnant women reported } \\
\text { being concerned about the } \\
\text { economic damage of the } \\
\text { pandemic. } \\
\text { Arab women presented more } \\
\text { anxiety related to COVID-19 } \\
\text { than Jewish women. }\end{array}$ & Low. & $\begin{array}{l}\text { - Sample that cannot be } \\
\text { considered representative of the } \\
\text { population of pregnant women in } \\
\text { Israel. } \\
\text { - Language in which the } \\
\text { instrument was presented } \\
\text { (Hebrew only). } \\
\text { - Differences in average age and } \\
\text { schooling levels among } \\
\text { participants. } \\
\text { - Absence of intervention. } \\
\text { - Without long-term follow-up. }\end{array}$ \\
\hline [30] & $\begin{array}{l}\text { Canada. } \\
900 \text { women, } 520 \text { pregnant and }\end{array}$ & $\begin{array}{l}\text { Analytical and } \\
\text { multicenter }\end{array}$ & $\begin{array}{ll}\text { EPDS } & \text { and } \\
\text { STAI. } & \end{array}$ & $\begin{array}{l}40.7 \% \text { of the pregnant women } \\
\text { presented high depression scores }\end{array}$ & Low. & $\begin{array}{l}\text { - Possible sampling bias. } \\
\text {-Data based on self-report }\end{array}$ \\
\hline
\end{tabular}




\begin{tabular}{|c|c|c|c|c|c|c|}
\hline & $\begin{array}{l}380 \text { in the first year after } \\
\text { childbirth, aged between } 17 \text { and } \\
49 \text { years. } 25 \text { with a history of } \\
\text { depression and } 60 \text { with a history } \\
\text { of anxiety. }\end{array}$ & $\begin{array}{l}\text { cross- } \\
\text { sectional } \\
\text { study. }\end{array}$ & & $\begin{array}{l}\text { during the pandemic and } \\
\text { moderate to high anxiety was } \\
\text { identified in } 72 \% \text { of the women } \\
\text { during the pandemic. } \\
\text { Nevertheless, women involved } \\
\text { in at least } 150 \text { minutes of } \\
\text { moderate-intensity physical } \\
\text { activity during the pandemic had } \\
\text { lower scores for both anxiety } \\
\text { and depression. }\end{array}$ & & $\begin{array}{l}\text { measures. } \\
\text { - Without long-term follow-up. } \\
\text { - Absence of support strategies. }\end{array}$ \\
\hline [31] & $\begin{array}{l}\text { Napoli, Italy. } \\
100 \text { women in the first, second } \\
\text { and third trimesters of pregnancy, } \\
\text { without history of postpartum } \\
\text { depression in a previous } \\
\text { pregnancy or psychiatric } \\
\text { disorders, evaluated from March } \\
15^{\text {th }} \text { to April } 1^{\text {st }}, 2020 .\end{array}$ & $\begin{array}{l}\text { Descriptive } \\
\text { cross- } \\
\text { sectional } \\
\text { study. }\end{array}$ & $\begin{array}{l}\text { IES-R, STAI } \\
\text { and VAS for } \\
\text { anxiety. }\end{array}$ & $\begin{array}{l}\text { Among the evaluated pregnant } \\
\text { women, } 53 \text { classified the } \\
\text { psychological impact of the } \\
\text { COVID-19 outbreak as severe } \\
\text { and } 68 \text { presented anxiety scores } \\
\text { above normal. } 46 \text { pregnant } \\
\text { women reported high anxiety } \\
\text { with regard to vertical } \\
\text { transmission of the disease. } \\
\text { The psychological impact and } \\
\text { the anxiety caused by the } \\
\text { COVID-19 pandemic were more } \\
\text { severe in women who are in the } \\
\text { first trimester of pregnancy than } \\
\text { in women who are in the second } \\
\text { and third trimesters of } \\
\text { pregnancy. }\end{array}$ & Low. & $\begin{array}{l}\text {-Restricted to a single institution. } \\
\text { - Data based on self-report } \\
\text { measures. } \\
\text { - Without long-term follow-up. } \\
\text { - Little information regarding } \\
\text { mental health care for pregnant } \\
\text { and puerperal women. }\end{array}$ \\
\hline
\end{tabular}

Source: authors.

Caption:

COVID-19 - Coronavirus Disease - 2019

RT-PCR - Reverse-Transcriptase Polymerase Chain Reaction 
SARS-CoV-2 - Severe Acute Respiratory Syndrome Coronavirus 2

GAD-7 - Generalized Anxiety Disorder 7-Item Scale

PHQ-9 - Patient Health Questionnaire-9

APIM - Actor-Partner Interdependence Model

FCV-19S - Fear of COVID-19 Scale

HADS - Hospital Anxiety and Depression Scale

SF-12 - 12-Item Short-Form Health Survey

PCV-19BS - Preventive COVID-19 Behavior Scale

HAMD-17 - Hamilton Depression Rating Scale for Depression

MADRS - Montgomery-Åsberg Depression Rating Scale

HAM-A - Hamilton Anxiety Rating Scale

EPDS - Edinburgh Postnatal Depression Scale

PROMIS - Patient-Reported Outcomes Measurement Information System

PRAQ - Pregnancy-related anxiety questionnaire

SSEQ - Social Support Effectiveness Questionnaire

ISEL - Interpersonal Support Evaluation List

K10 - 10-Item Kessler Psychological Distress Scale

PCL-5 - Posttraumatic Stress Disorder Checklist 5

DES $\square$ II - Dissociative Experiences Scale

PANAS - Positive and Negative Affect Schedule

EDS - Edinburgh Depression Scale

MIBS-J - Mother-Infant Bonding Scale

PHQ-2 - Patient Health Questionnaire-2

BRS - Brief Resilience Scale

WEMWBS - Warwick-Edinburgh Mental Well-Being Scale

SAS - Self-Rating Anxiety Scale

SSRS - Social Support Rating Scale

MHI-5 - Five-Item Mental Health Inventory

STAI - State-Trait Anxiety Inventory

IES-R - The Impact of Events Scale - Revised

VAS - Visual Analogue Scale 
The analysis of the articles enabled us to observe the following characteristics: all articles were published in the year 2020, carried out in 13 different countries, including the United Kingdom [14,20], Iran [15], India [16], China [17,19,25], Canada [18,21,30], Belgium [22], Japan [23], United States [24], Italy [26,31], Australia [27], Ireland [28] and Israel [29].

A total of 10 studies adopted a descriptive cross-sectional design [14,15,18,20,22,25,27,28,29,31], one multicenter cross-sectional [19], one analytical crosssectional [23], one analytical and multicenter cross-sectional [30], three case reports $[16,17,26]$, one from a prospective cohort [21] and one from a mixed exploratory method [24].

Anxiety and depression were the main identified outcomes, being shown in 15 $[14,16,17,18,19,20,21,22,24,25,27,28,29,30,31] \quad$ and 11 studies [14, $15,17,18,19,20,21,22,23,24,30]$, respectively. Other outcomes identified in more than one study were: concerns related to several factors [17,18,27,28]; loneliness [18,20,24]; stress $[24,27]$ and fear $[15,16]$. The studies evaluated anxiety from several scales: three studies using the Generalized Anxiety Disorder 7-Item Scale - GAD-7 [14,22,24], two using the State-Trait Anxiety Inventory - STAI) [30,31], one using the Hospital Anxiety and Depression Scale - HADS [15] and one using the Hamilton Anxiety Rating Scale - HAMA) [17]. Another study also used the Self-Rating Anxiety Scale - SAS [25], and another the Pregnancy-related Anxiety Questionnaire - PRAQ [18]. Moreover, two studies evaluated anxiety using specific instruments [20,29].

Depression was evaluated in: one study using the Patient Health Questionnaire-9 - PHQ-9 [14], one using the Hospital Anxiety and Depression Scale - HADS) [15], one using the Hamilton Depression Rating Scale for Depression - HAM-D-17 [17], one using the Montgomery-Åsberg Depression Rating Scale - MADRS [17], four studies using the Edinburgh Postnatal Depression Scale - EPDS [18,19,23,30], two using the Patient Health Questionnaire-2 - PHQ-2 [17,24] and another study using the Edinburgh Depression Scale (EDS) [22]. Another study also used its own instrument to evaluate depression [20].

Moreover, the fear of COVID-19 was evaluated in one study using the Fear of COVID-19 Scale - FCV-19S) [15]; mental well-being in one study using the WarwickEdinburgh Mental Well-Being Scale - WEMWBS) [24]; quality of life in one study using the 12-Item Short-Form Health Survey - SF-12) [15]; preventive behavior in one study using the Preventive COVID-19 Behaviour Scale (PCV-19BS); psychological distress in 
medRxiv preprint doi: https://doi.org/10.1101/2020.08.17.20176560; this version posted August 21, 2020. The copyright holder for this preprint

one study using the 10-Item Kessler Psychological Distress Scale - K10) [21]; posttraumatic stress disorder in two studies, one using the Posttraumatic Stress Disorder Checklist 5 - PCL-5 [21] and the other using the Impact of Events Scale-Revised - IES-R) [31]; positive and negative affects in one study using the Positive and Negative Affect Schedule - PANAS) [21]; one study evaluated social support through the Social Skills, Behavior Problems and Academic Competence Inventory for Children (SSRS) [25] and two studies evaluated psychological stress and well-being through the Five-Item Mental Health Inventory - MHI-5 [29] and the Visual Analogue Scale - VAS [31], respectively.

Among the 18 analyzed studies, 11 signalized a low level of evidence $[14,16,18,19,20,21,22,28,29,30,31]$ and seven very low levels [15,17,23,24,25,26,27].

\section{DISCUSSION}

The results showed that the study population was mentally affected by the onset of symptoms of anxiety, depression, fear, suicidal thoughts, psychomotor agitation, irrelevant speech, crying spells, delusions of persecution and greatness, catatonic symptoms of mutism, bad mood, irritability, excessive concerns, thoughts of self-mutilation, social isolation, loneliness, stress, resilience and poor well-being.

Depression, fear, anxiety and other psychotic symptoms referred to are configured in the main psychological repercussions that affect the mental health of pregnant and puerperal women during the pandemic period of COVID-19, thus reflecting the sociopolitical-cultural context in which we live and its challenging capacity. The current pandemic scenario triggered by COVID-19 and the consequent mitigation measures (social detachment, quarantine and social isolation) have entailed the intensification of psychological distress for certain groups, which can include women in the pregnancypuerperal cycle.

This is because pregnancy and postpartum, commonly, are already characterized as periods of hormonal, bodily and psychological changes in women's lives, adding, in the current scenario, a pandemic disease with transmission routes still unclear, but that can threaten maternal and child health. Thus, the experience of a continuous pandemic situation and the lack of certainty about the future at this moment can be factors causing stress, anxiety, fear and other symptoms, since without information, they do not know how to proceed to protect themselves and their babies. This situation has already been reported as recurrent in outbreaks related to other infectious diseases such as H1N1 Influenza, Ebola, 
medRxiv preprint doi: https://doi.org/10.1101/2020.08.17.20176560; this version posted August 21, 2020. The copyright holder for this preprint

Middle East Respiratory Syndrome (MERS), Severe Acute Respiratory Syndrome (SARS) and Zika Virus [32,33].

Although the vertical transmission of Severe Acute Respiratory Syndrome Coronavirus 2 (SARS-CoV-2) is not clear, we cannot rule out: concerns about the possibility of premature birth; the chances of cesarean section in cases of idealized vaginal birth; the lack of humanization during childbirth; the impossibility of breastfeeding; the newborn being isolated from the mother, or the mother and the newborn being isolated from family members and close acquaintances; besides the fear of being infected or the baby being or being infected by other people [32,33].

The fear of being infected by COVID-19 is very distressing, mainly because it still does not have scientifically proven treatment. Social detachment, a primary measure to contain the proliferation of the virus, made people physically isolate themselves from family members, friends, their tasks and the community, a measure that affected the mental health and psychological well-being of pregnant and puerperal women [18].

In this sense, depressive symptoms were widely identified in studies $[14,15,17,18,19,20,21,22]$, despite the limiting difference observed in culture studies, methods and instruments used, as well as in the fear of being infected by infectious diseases, which was significantly associated with depression, stress and anxiety $[15,17,18,19,20,21,22,27,28,29,30,31]$, where only one study performed in the United Kingdom [14] with women aged 18 to 39 years, from the $27^{\text {th }}$ to the $39^{\text {th }}$ weeks of pregnancy, presented a difference in the results, and this was due to the increase in information available about COVID-19 and to the guarantee offered to the population in question with respect to primary care and health professionals.

Symptoms of stress, depression and anxiety related to COVID-19 have shown a negative effect, thus impacting the mental health of the general population $[34,35,36]$. A research conducted at the beginning of the COVID-19 outbreak in Wuhan, China, found that $53.8 \%$ of the participants presented symptoms of anxiety and depression (moderate and severe), $17 \%$ and $29 \%$, respectively [6].

Psychological disorders such as depression and anxiety, more present in the lives of pregnant and puerperal women in this pandemic period, have caused serious problems, with a consequent reduction in the quality of life of these individuals. Thus, there is a need to guarantee emotional support, in order to mitigate the fear of this illness [18]. Increased social and emotional support contributes to the reduction of psychological distress and to the maintenance of physical well-being, as well as family and partner support is of utmost 
importance in this process of social detachment [15], in addition to the issue of resilience [ 14], which helps us to cope well with severe situations such as the pandemic period.

Conversely, women without history of pre-existing mental illnesses who did not have support and suffered external pressure caused by third parties had psychotic breaks [16], others with a family history of bipolar disorder and, without support, also had psychotic characteristics $[21,26]$. Given this situation, we should observe that the infection and the fear of COVID-19 go beyond the organic issue, pointing to mental and social issues, by generating psychological exhaustion, especially for the most vulnerable people who feel unsupported.

One of the studies raised in this review pointed out that mental health problems are prevalent in women with younger ages, low family income and lower schooling level [21]. Common Mental Disorders (CMD) are challenging for health services, as they have grown alarmingly in the last few years. In particular, the occurrence of these disorders has increased in women, since they are twice as likely to develop the disorder as men, mainly when they are in the periods of pregnancy and puerperium [37].

Women in situations of risk of vulnerability, poverty, without a steady partner, young, with hereditary or congenital characteristics and low schooling levels have evolved with depressive and anxious symptoms not only in maternal health, but also fetal, which highlights the importance of screening and following-up during pregnancy and puerperium $[38,39,40,41]$.

Moreover, many women experienced increased psychological stress, as they did not have the necessary help in the service unit, as well as support when breastfeeding. After childbirth, women may feel helpless, where the lack of support is a factor that can directly affect the breastfeeding process. [21].

Based on studies by Thomson, Ebisch-Burton and Flacking [42], it is common for women to have the need to carry out breastfeeding, so that those who do not can feel that they have failed. Nevertheless, according to the authors, both mothers who do not breastfeed and those who breastfeed may suffer from the absence of support and inconvenient judgment, which can even result in feelings of inadequacy and isolation [42]. Such notes show that the scenario related to COVID-19 may be the aggravating factor in the face of the issue that involves complications and the need for attention even outside the pandemic period. 
Some limitations should be considered when interpreting the results of this systematic review. We noted a heterogeneity in the studies, the use of different instruments for data collection and distinct follow-up times.

\section{CONCLUSION}

From this review, we can infer that the COVID-19 pandemic has impacted the mental health of pregnant and puerperal women. The results have revealed the main changes in the mental health of this population, with depression and anxiety being the most frequent. Several concerns, loneliness, fear, stress, suicidal thoughts, psychosis, agitation, delusions of persecution and overvalued ideas were also present.

The current pandemic scenario triggered by COVID-19 and the consequent social detachment, the media pressure, the fear of contracting the infection, the economic scenario and the rupture of family rituals resulted in observable intensifications of psychological distress, thus causing changes in the mental health of these women.

\section{REFERENCES}

[1] Wu F, Zhao S, Yu B, Chen Y, Wang W, Song Z, et al. A new coronavirus associated with human respiratory disease in China. Nature. 2020;579(7798):265-9. doi: 10.1038/s41586-020-2008-3.

[2] Ministério da Saúde (BR). Protocolo de manejo clínico do coronavírus (COVID-19) na Atenção Primária à Saúde [Internet]. Brasília, DF: Ministério da Saúde; 2020a. Available from: https://www.unasus.gov.br/especial/covid19/pdf/37.

[3] Albuquerque LP, Silva RB, Araújo RMS. COVID-19: origin, pathogenesis, transmission, clinical aspects and current therapeutic strategies. Rev Pre Infec e Saúde [Internet]. 2020;6:10432. Available from: https://doi.org/10.26694/repis.v6i0.10432

[4] Zhu N, Zhang D, Wang W, Li X, Yang B, Song J, et al. A novel coronavirus from patients with pneumonia in China, 2019. N Engl J Med. 2020;382(8):727-33. doi: 10.1056 / NEJMoa2001017.

[5] Ministério da Saúde, Agência Nacional de Vigilância Sanitária (BR). Orientações Gerais - Máscaras Faciais de Uso Não Profissional. Brasília, DF: Ministério da Saúde; $2020 \mathrm{~b}$ Available

from: http://portal.anvisa.gov.br/documents/219201/4340788/NT+M\%C3\%A1scaras.pdf/bf43018 4-8550-42cb-a975-1d5e1c5a10f7. 
[6] Wang C, Pan R, Wan X, Tan Y, Xu L, Ho CS, et al. Immediate psychological responses and associated factors during the initial stage of the 2019 coronavirus disease (COVID-19) epidemic among the general population in China. Int $\mathbf{J}$ Environ Res Public Health. 2020;17(5):1729. doi: 10.3390/ijerph17051729.

[7] Ministério da Saúde, Secretaria de Atenção Especializada à Saúde. Departamento de Atenção Hospitalar, Domiciliar e de Urgência (BR). Protocolo de manejo clínico da Covid19 na Atenção Especializada. $1^{a}$ ed. rev. Brasília, DF: Ministério da Saúde; 2020c. Available from: https://bvsms.saude.gov.br/bvs/publicacoes/manejo_clinico_covid19_atencao_especializada.pdf.

[8] Ministério da Saúde, Secretaria de Atenção Primária à Saúde. Departamento de Ações Programáticas Estratégicas (BR). Nota técnica COSMU/CGCIVI/DAPES/SAPS/MS n ${ }^{\circ}$ 12/2020: Infecção COVID-19 e os riscos às mulheres no ciclo gravídico-puerperal. Brasília, DF: Ministério da Saúde; 2020d. Available from: https://portaldeboaspraticas.iff.fiocruz.br/biblioteca/nota-tecnica-no-12-2020-cosmu-cgcividapes-saps-ms/.

[9] Bessa MM, Lima LS, Rocha JMC, Oliveira IV, Freitas RJM. Psychosocial and mental health aspects in the face of social distance due to the COVID-19 pandemic. Rev Pre Infec e Saúde [Internet]. 2020;6:10414. Available from: https://doi.org/10.26694/repis.v6i0.10414

[10] Hoffmann M, Kleine-Weber H, Schroeder S, Krüger N, Herrler T, Erichsen S, et al. SARS-CoV-2 Cell Entry Depends on ACE2 and TMPRSS2 and Is Blocked by a Clinically Proven Protease Inhibitor. Cell. 2020;181(2):271-80:e8. doi: 10.1016/j.cell.2020.02.052.

[11] The Joanna Briggs Institute. Joanna Briggs Institute Reviewers' Manual: 2020 edition. Adelaide: The University of Adelaide; 2014.

[12] Moher D, Liberati A, Tetzlaff J, Altman DG, The PRISMA Group (2009). Preferred Reporting Items for Systematic Reviews and Meta-Analyses: The PRISMA Statement. PLoS Med 6(7): e1000097. doi:10.1371/journal.pmed1000097

[13] Guyatt G, Oxman AD, Akl EA, Kunz R, Vist G, Brozek J, et al. GRADE guidelines: 1. Introduction-GRADE evidence profiles and summary of findings tables. J Clin Epidemiol 2011;64(4):383-94. https://doi.org/10.1016/j.jclinepi.2010.04.026

[14] Kotabagi P, Fortune L, Essien S, Nauta M, Yoong W. Anxiety and depression levels among pregnant women with COVID $\square$ 19. Acta Obstet Gynecol Scand. 2020; 99:953-54. DOI: https://doi.org/10.1111/aogs.13928

[15] Ahorsu DK, Imani V, Lin CY, Timpka T, Broström A, Updegraff JA, et al. Associations Between Fear of COVID-19, Mental Health, and Preventive Behaviours Across Pregnant Women and Husbands: An Actor-Partner Interdependence Modelling. Int J Ment Health Addiction. 2020; 1-15. [Epub ahead of print]. DOI: https://doi.org/10.1007/s11469-020-00340-x 
[16] Chandra PS, Shiva L, Nagendrappa S, Ganjekar S, Thippeswamy H. COVID 19 related Psychosis as an interface of fears, socio-cultural issues and vulnerability- case report of two women from India. Psychiatry Res. 2020; 290:113136. [Epub ahead of print]. DOI: https://doi.org/10.1016/j.psychres.2020.113136

[17] Huang JW, Zhou XY, Lu SJ, Xu Y, Hu JB, Huang ML, et al. Dialectical Behavior Therapy-Based Psychological Intervention for Woman in Late Pregnancy and Early Postpartum Suffering From COVID-19: A Case Report. J Zhejiang Univ Sci B. 2020; 21(5):394-99. DOI: https://doi.org/10.1631/jzus.B2010012

[18] Lebel C, MacKinnon A, Bagshawe M, Tomfohr-Madsen L, Giesbrecht G. Elevated depression and anxiety among pregnant individuals during the COVID-19 pandemic. PsyArXiv. 2020. DOI: https://doi.org/10.31234/osf.io/gdhkt

[19] Wu Y, Zhang C, Liu H, Duan C, Li C, Fan J, et al. Perinatal depressive and anxiety symptoms of pregnant women along with COVID-19 outbreak in China. Am J Obstet Gynecol. 2020; S0002-9378(20)30534-2. [Epub ahead of print]. DOI: https://doi.org/10.1016/j.ajog.2020.05.009

[20] Vazquez-Vazquez A, Dib S, Rougeaux E, Wells JC, Fewtrell M. The impact of the Covid-19 lockdown on the experiences and feeding practices of new mothers in the UK: Preliminary data from the COVID-19 New Mum Study. medRxiv. 2020. DOI: https://doi.org/10.1101/2020.06.17.20133868

[21] Berthelot N, Lemieux R, Garon-Bissonnette J, Drouin-Maziade C, Martel E, Maziade M. Uptrend in distress and psychiatric symptomatology in pregnant women during the coronavirus disease 2019 pandemic. Acta Obstet Gynecol Scand. 2020; 99(7):848-55. DOI: https://doi.org/10.1111/aogs.13925

[22] Ceulemans M, Hompes T, Foulon V. Mental Health Status of Pregnant and Breastfeeding Women During the COVID-19 Pandemic: A Call for Action. Int J Gynaecol Obstet. 2020. [Epub ahead of print]. DOI: https://doi.org/10.1002/ijgo.13295

[23] Suzuki S. Psychological status of postpartum women under the COVID-19 pandemic in Japan. J Matern Fetal Neonatal Med. 2020; 1-3. [Epub ahead of print]. DOI: https://doi.org/10.1080/14767058.2020.1763949

[24] Farewell CV, Jewell J, Walls J, Leiferman JA. A mixed-methods pilot study of perinatal risk and resilience during COVID-19. J Prim Care Community Health. 2020; 11:11:2150132720944074. [Epub ahead of print]. DOI: https://doi.org/10.1177/2150132720944074

[25] Yue C, Liu C, Wang J, Zhang M, Wu H, Li C, et al. Association between social support and anxiety among pregnant women in the third trimester during the coronavirus disease 2019 (COVID-19) epidemic in Qingdao, China: The mediating effect of risk perception. Int J Soc Psychiatry. 2020; 20764020941567. [Epub ahead of print]. DOI: https://doi.org/10.1177/0020764020941567 
[26] Franchi M, Del Piccolo L, Bosco M, Tosadori C, Casarin J, Lagana' AS, et al. Covid19 and mental health in the obstetric population: a lesson from a case of puerperal psychosis. Minerva Ginecol. 2020; 10.23736/S0026-4784.20.04606-7. [Epub ahead of print] DOI: https://doi.org/10.23736/s0026-4784.20.04606-7

[27] Hull N, Kam RL, Gribble KD. Providing breastfeeding support during the COVID-19 pandemic: Concerns of mothers who contacted the Australian Breastfeeding Association. medRxiv. 2020. DOI: https://doi.org/10.1101/2020.07.18.20152256.

[28] Corbett GA, Milne SJ, Hehir MP, Lindow SW, O'connell MP. Health anxiety and behavioural changes of pregnant women during the COVID-19 pandemic. European journal of obstetrics, gynecology, and reproductive biology. 2020; 249, 96-97. DOI: https://doi.org/10.1016/j.ejogrb.2020.04.022

[29] Taubman-Ben-Ari O, Chasson M, Sharkia SA, Weiss E. Distress and anxiety associated with COVID-19 among Jewish and Arab pregnant women in Israel. J Reprod Infant Psychol. 2020;38(3):340-348. DOI: https://doi.org/10.1080/02646838.2020.1786037

[30] Davenport MH, Meyer S, Meah VL, Strynadka MC, Khurana R. Moms Are Not OK: COVID-19 and Maternal Mental Health. Front. Glob. Women's Health. 2020; 1:1. DOI: https://doi.org/10.3389/fgwh.2020.00001.

[31] Saccone G, Florio A, Aiello F, Venturella R, De Angelis MC, Locci M et al. Psychological impact of coronavirus disease 2019 in pregnant women. American Journal of Obstetrics and Gynecology. 2020; 223, 2, 293-295. DOI: https://doi.org/10.1016/j.ajog.2020.05.003

[32] Sousa AFL, Carvalho HEF, Oliveira LB, Schneider G, Camargo ELSC, Watanabe E, Andrade D, Fernandes AFC, Mendes IAC, Fronteira I. Effects of COVID-19 infection during pregnancy and neonatal prognosis: what is the evidence. International Journal Of Environment Research and Public Health. 2020

[33] Alves SHS, Siqueira HCH, Pereira QLC. Ser gestante no meio repelente: orientações, medidas preventivas e ansiedade frente ao diagnóstico positivo para o Zika Vírus. Enfermería Actual de Costa Rica. 2019;(36):48-61. http://dx.doi.org/10.15517/revenf.v0i36.33153.

[34] Hamel L, Salganicoff A. Is there a widening gender gap in coronavirus stress? [Internet]. Kaiser Family Foundation: Coronavirus Poll. 2020. Available from: https://www.kff.org/coronavirus-policy-watch/is-there-widening-gender-gap-incoronavirus-stress/.

[35] Asmundson GJG, Taylor S. Coronaphobia: fear and the 2019-nCoV outbreak. J Anxiety Disord. 2020;70:102196. doi: 10.1016/j.janxdis.2020.102196.

[36] Carvalho PMM, Moreira MM, Oliveira MNA, Landim JMM, Rolim Neto ML. The psychiatric impact of the novel coronavirus outbreak. Psychiatry Res. 2020;286:112902. doi: 10.1016/j.psychres.2020.112902. 
medRxiv preprint doi: https://doi.org/10.1101/2020.08.17.20176560; this version posted August 21, 2020. The copyright holder for this preprint (which was not certified by peer review) is the author/funder, who has granted medRxiv a license to display the preprint in perpetuity.

It is made available under a CC-BY-NC 4.0 International license .

[37] Organização Mundial da Saúde (OMS). Classificação dos transtornos mentais e de comportamentos da CID-10: descrições clínicas e diretrizes diagnósticas. Porto Alegre (RS): Artes Médicas; 2009.

[38] Bitew T, Hanlon C, Kebede E, Honikman S, Fekadu A. Antenatal depressive symptoms and perinatal complications: a prospective study in rural Ethiopia. BMC Psychiatry. 2017 Aug;17(1):301. doi: 10.1186/ s12888-017-1462-4

[39] Hartmann JM, Mendoza-Sassi RA, Cesar JA. Postpartum depression: prevalence and associated factors. Cad Saúde Pública. 2017 Oct 9;33(9):e00094016. doi: 10.1590/0102311 X00094016.

[40] Lau Y, Htun TP, Kwong HKD. Sociodemographic, obstetric characteristics, antenatal morbidities, and perinatal depressive symptoms: A three-wave prospective study. PLoS ONE. 2018; 13(2):e0188365. PMCID: PMC5805167. doi: 10.1371/journal.pone.0188365.

[41] Kohlhoff J, Hickinbotham R, Knox C, Roach V, Barnett Am B. Antenatal psychosocial assessment and depression screening in a private hospital. Aust N Z J Obstet Gynaecol. 2016 Apr; 56(2):173-8. doi: 10.1111/ajo.12418.

[42] Thomson G, Ebisch-Burton K, Flacking R. Shame if you do-shame if you don't: women's experiences of infant feeding. Matern Child Nutr. 2015; 11(1): 33-46. DOI: https://doi.org/10.1111/mcn.12148 